\title{
歩道境界空間デザインを考慮した VR歩行空間評価
}

\author{
守田 賢司1・中村 一樹2 \\ 1学生会員 名城大学大学院 理工学研究科社会基盤デザイン工学専攻 \\ （†466-8502 名古屋市天白区塩釜口1-501） \\ E-mail: 150448104@ccalumni.meijo-u.ac.jp \\ 2正会員 名城大学准教授 理工学部社会基盤デザイン工学科（†466-8502 名古屋市天白区塩釜口1-501） \\ E-mail:knaka@meijo-u.ac.jp
}

\begin{abstract}
歩行空間には，通行や車両利用に関する利便・安全，路上の滞留活動に関する快適・楽しさなど様々な 歩行ニーズに関する機能があり, これらは歩道の車道や建物との境界空間で多く見られる. しかし, 歩行 空間整備は個別の機能に注目し, ある機能のデザイン要素の整備が他の機能に有効かは十分に検討されて いるとは言い難い。そこで，本研究では，国際的に多様な歩行空間をVRで評価し，歩道の境界空間デザ インが歩行空間評価に与える影響を分析する。まず，国内外のケーススタディ地区におけるデザインの違 いを把握する。 そして，VRツールを用いてこれらの歩行ニーズの評価の実験調查を行い，デザインとの 関係を分析する。この結果, 境界空間デザインは複数の歩行ニーズに大きく関係し, 建物側と車道側でそ れらの関係が異なることが明らかになった。
\end{abstract}

Key Words : street edge, in-between space, walkability, VR, international comparison

\section{1. はじめに}

モータリゼーション期において，道路開発は自動車利 用を中心に行われてきたため, 歩行者のための空間整備 の優先度は低かった。 日本でも, 歩道整備は車両通行の 障害にならないよう歩行者との接触を減らし，利便性と 安全性の観点からそれぞれの最低限の通行空間を確保す ることが主に取り組まれてきた。 しかし，近年の環境問 題や人口減少・高齢化といった大きな社会二ーズの変化 により，都市はコンパクト化を中心とした脱車依存のビ ジョンへと転換し，この中で歩行空間の役割が見直され つつある.

また，歩行空間を改善する上で，利便性，安全性だけ でなく快適性や楽しさも含めた多様な歩行ニーズの観点 から，歩きたくなる歩行空間を提供することが重要とさ れている1). 特に, 歩行者の興味は，立ち止まる・座る という滞留行動を伴う路上活動に惹きき付けられること が示されている2). このような滞留行動は歩道の建物側 の境界空間で起こる傾向があると言われているが，日本 の道路では，ベンチ・オープンカフェなどの滞留機能を 持つデザイン要素はまだ少ない.

一方で, 近年の交通システムの変化も, 歩行空間のデ
ザインを変え歩行ニーズに大きく影響する可能性がある. 自転車・車のシェアリングや自動運転の活用などの取り 組みは，歩道と車道の間での交通の乗り降りの需要を増 やすと考えらえる.これには，路上での通行・交通の利 便性・安全性だけでなく, 待合のための滞留の快適性・ 楽しさの向上も必要となる.しかし，これらの歩行空間 の交通機能が高まるにつれ, 歩行通行者, 車両, 路上活 動の間の障害が生じる可能性もある. 従って, 通行・滞 留・交通機能に関する歩行空間のデザインを，境界空間 のデザイン要素を考慮して, 様々な歩行ニーズの観点か ら評価することが重要である.

このような歩行空間評価には, 歩行における多様な二 一ズに関する空間の経験が影響すると考えられる．日本 における一般的な歩行空間整備では，利便性と安全性を より重視した通行空間の整備が進められてきたが，快適 性や楽しさを考慮した滞留空間の整備はまだ少ない. そ のため，国内外の多様な歩行空間の経験が必要であるが， 実際に評価したい海外の歩行空間を歩くことは現実的で はない. そこで，近年発展している視覚化技術として， VRツールを用いることで，様々な歩行空間を疑似的に 体験することができると考える. 例えば，一般的に利用 可能なVRツールとして，360度の空間を動画で撮影でき 
る360度カメラや，頭部の動きで視界を選んで視聴でき るへッドマウンドディスプレイ (HMD) は, このよう な疑似歩行を可能とする，VRによる疑似歩行は，五感 に基づく日常の経験とは異なり，視覚による一時的な体 験に止まるが，VRの四次元空間情報について利便・安 全・快適・楽しさといった基本的な歩行ニーズを知覚す ることは可能と思われる，VRツールは都市計画の合意 形成にも活用が検討されつつあり，評価ツールとしてだ けでなく, 情報発信ツールとしても関心が高まっている. これらを踏まえ, 本研究では, VR ツールを使用して, 建物側と車道側で多い境界空間デザインが歩行空間評価 へ与える影響を分析する.まず，国内外の都市の歩行空 間のケーススタディ地区のデザインを計測し，ケースス タディ地区におけるデザインの多様性を把握する. 次に, VR ツールを用いて歩行空間デザイン評価の実験を行う。 最後に，歩行空間デザイン評価と歩行ニーズ評価を比較 して, 歩行空間の境界デザインと歩行空間評価の関係を 分析する.

\section{2. 歩行空間デザインの定量化}

\section{(1) デザイン要素の整理}

歩行空間デザイン評価の既往研究をレビューし，境界 空間のデザインを考慮してデザイン要素を整理した. 境界空間デザインの研究として, Gehl and Svarre ${ }^{2)}$ は，人 の関心を惹いて歩行空間に賑わいを生多出す要素として 人の路上活動（アクティビティ）が重要だということを 示している. アクティビティは, 立つ, 歩く, 座る, の 3 つの行動を基本として行われているが, この行動に伴 うアクティビティは大きく 3 つに分けられる. まず, 必 要活動は, 買い物や乗換えなど日常生活に必要な移動で 歩行環境に関わらず行われる，次に，任意活動は，散策， ジョギング，座って休憩などの歩行者の帯留行動で，歩 行環境の質が活動発生に大きく影響する．任意活動を誘 発するデザイン要素として, ベンチ, 露店やオープンカ フェなどが挙げられている.これらは歩道の通行空間と 建物側の境界空間である道の端（エッジ）に多くあり， 人々はエッジ部分に溜まりやすいことが示されている. さらに，社会活動は，他者の存在が成立条件となる会話 や路上活動などで，任意活動をさらに誘発するとされて いる.よって，滞留空間のデザインとして，人のような 動的な要素も重要となる.

また，より包括的な歩行空間デザインの研究として, Ewing and Bartholomew ${ }^{3)}$ は，アメリカの歩行空間の様々な 事例に基づいて，デザイン要素を重要度別に整理してい る.ここでは，歩行空間の歩きやすさ（Walkability）を 構成する主要素として, 客観的デザイン要素, 主観的デ
ザイン要素, 知覚的要素で整理している. その評価の枠 組みとして，客観的なデザインは，主観的に捉えられ， 知覚的な歩行ニーズで評価されるとしている. 歩行空間 に最も重要なデザイン要素としては，土地利用（中高密 度，用途混合の土地利用，ブロック短さ），交通（車道 レーン少なさ，安全な横断，バス停近さ）, 歩道（連続 した歩道）と，それらの境界空間デザイン（通りに適し た建物，快適で安全な休憩場所，歩車道間の緩衝帯）を 抽出している.

国内の境界空間デザインを見ている研究として，建物 側では，藤本ら 4)が，オープンカフェが周辺地区に与え る影響を調査分析している. オープンカフェがオープン する前後の通行量と滞在時間を比較し, 公共空間の商業 活用に対しての周辺住民の評価を調査している.この結 果，オープンカフェがあることで，平日の通行量は約 1.4倍，休日の通行量は約3倍に増加し，店舗の滞留時間 も 30〜40 分となり, 単なる通過交通量の増加だけでな く，人が滞留する効果が確認された. 周辺住民の意識も， 公共空間の商業活用に対して，約 $70 \%$ の人がオープンカ フェ開業の方が良く, 周囲の安全性の向上に繫がったと 感じていることが明らかになった.

有馬ら 5), 商業地街路の空間特性, 行動誘発要素, そしてアクティビティとの 3 つ関連を分析している. ここでは，商店街内の街路に面した店舗の入り口の開口 部を，街路に面した部分が全て壁になっている店舗，壁 がない店舗, 全面がガラス張りになっている店舗, 半分 がガラス張りになっており，残りは壁になっている店舗 の 4 つのファサドタイプに分類した. そして, 看板, ショーウィンド, ショーケース, テーブルやいす, 立て 看板，などを歩行者行動誘発要素として分類した. この 結果, ファザードタイプ, 行動誘発要素, アクティビテ イには関係があり，より開放的なファザードが購買活動 のアクティビティを誘発することが示された． 街路にお ける空間特性は歩行行動の分析では，魅力的な空間で歩 行速度が遅くなり，歩道の建物側に商品が並ぶ空間では 歩行速度が遅くなることも報告されているの.

車道側の境界空間デザインの研究として，谷口ら ${ }^{7}$ 商店街における自動車交通が歩行者に及ぼす心的影響を ヒアリングアンケート調査から分析している。この結果, 商店街の自動車規制時間帯がある歩行者天国では, 歩き やすさ, 雰囲気の良さ, 楽しさの主観的な歩行者の街路 評価指標が, 自動車規制されてない時間帯に比べ高い評 価になった. 特に, 自動車の路上駐車が, 歩行者にとっ ての歩きやすさ, 雰囲気の良さ, 楽しさの 3 つの街路評 価に否定的影響を及ぼしていた，そして，走行する自動 車は路上駐車に比べて格段に否定的影響が強いことが示 されている.また，自転車も自動車と同様に否定的影響 を及ぼしていることが示された。 
また, 藤居・酒井 ${ }^{81}$ は, 低木, 高木, 歩者分離施設, 歩道幅, 歩道デザインの 5 つの景観要素が街路景観に対 して与える影響をアンケート調査によるコンジョイント 分析で評価している.この結果, 街路の総合評価におい て，低木や高木などの街路樹の存在が街路景観に対して 非常に高い評価を与えることが示された，特に，街路樹 は, 現代性, 開放感, 安らぎ感, 爽快感の 4 つの評価因 子の中で，安らぎ感に最も影響を与えることが示された。

以上のレビューから, 既往研究では歩道の様々な境界 空間のデザイン要素が歩行空間評価に与える影響を示し ていることが分かった. しかし，これらのデザイン要素 を包括的に評価している研究は見られない.

これらを踏まえて, 本研究では, 建物, 歩道, 車道に ある包括的な歩行空間デザイン要素を分析対象とし，人 や車両といった動的な要素も含めて, 主なデザイン指標 を整理した（表-1）。歩道，建物，車道は，それぞれ整 備主体が異なり，整備は主体別に個別で行われ，その一 体整備には主体間の連携が必要なので, それぞれを分け て考慮した. また, 人の路上活動や車両といった時間に よる変化を伴う動的な要素も考慮し, 人の活動は建物側 の境界空間に多く, 車両は車道側の境界空間に多いと考 えられるため，それぞれに関する指標を抽出した．ただ し，境界空間のデザイン要素は必ずしもこれに限定する ものではないことに留意が必要である.

\section{（2）デザイン要素の国際比較}

歩行空間デザインは国や都市によって大きく異なり， 特に, 境界空間デザインは違いが大きいと考えられる. そこで本研究では，多様な歩行空間デザインを調査寸る 対象として, 名古屋, バンコク, ブリスベン, キャンベ ラの 4 つの都市の都心部中心駅周辺の大通りをケースス タディ地区として選んだ（図-1）。これらの都市は, 車 依存度が高い大都市であるが, 歩行空間の整備は大きく 異なる. 本調查では, 歩行ニーズの要素が特徵的なケー ススタディとして，都心部は交通渋滞が深刻で歩行環境 の利便性と安全性が低いと考えられるバンコクと, 都心 部に歩行者専用ゾーンを導入して快適性と楽しさが高い と考えられるブリスベン・キャンベラを，対照的な地区 として位置付けている. 名古屋都心部は, デパートなど の高いビルが立ち並ぶ大通りを中心に整備され，車の幹 線道路と歩行者の目抜き通りが同じ大通りとなっており， この大通りの 1 つである栄駅周辺の久屋大通りのルート を対象とした。 バンコク都心部は，道路交通量が多く歩 道整備は遅れているが，高架鉄道スカイトレインの沿線 には駅と接続した商業施設が並んでおり, アソーク駅周 辺の商業施設を出て裏通り（Soi）から大通へと通るル 一トを対象とした．ブリスベンは，欧米の都市と同様に 歩行者専用ゾーンの商業地区が中心にあり，このゾーン
表-1 本研究で使用するデザイン指標

\begin{tabular}{|l|l|l|l|l|}
\hline \multicolumn{1}{|c|}{ デザイン指標 } & 建物 & 歩道 & 車道 & 動的 \\
\hline 周りの建物の高さ & $\bigcirc$ & & & \\
\hline 中が見える施設の数 & $\bigcirc$ & & & \\
\hline 屋根のある歩道の長さ & $\bigcirc$ & $\bigcirc$ & & \\
\hline ベンチの数 & $\bigcirc$ & $\bigcirc$ & & \\
\hline 露店の数 & & $\bigcirc$ & & \\
\hline 立止まる・座る人の数 & & $\bigcirc$ & & $\bigcirc$ \\
\hline 歩道幅 & & $\bigcirc$ & & \\
\hline 歩行者の数 & & $\bigcirc$ & & $\bigcirc$ \\
\hline 街灯の数 & & $\bigcirc$ & & \\
\hline 駐輪の数 & & $\bigcirc$ & & $\bigcirc$ \\
\hline 緑・街路樹の数 & & $\bigcirc$ & $\bigcirc$ & \\
\hline 電柱の数 & & $\bigcirc$ & $\bigcirc$ & $\bigcirc$ \\
\hline 駐車の数 & & & $\bigcirc$ & \\
\hline 横断歩道の幅 & & & $\bigcirc$ & $\bigcirc$ \\
\hline 交通量の数 & & & \\
\hline
\end{tabular}

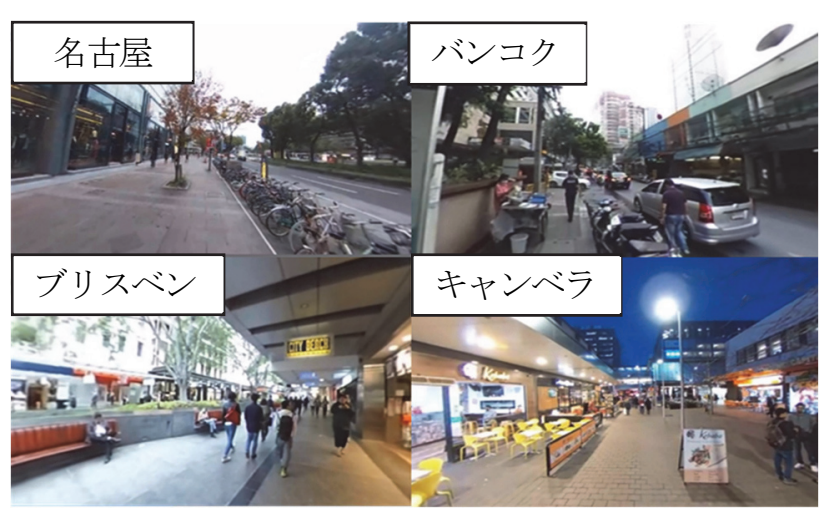

図-1 本研究のケーススタディ地区

を通るセントラル駅周辺のルートを対象とした. キャン ベラは，より計画的に造られた都市ではあるが，軌道系 交通は少なく車中心であり, 道路幅も歩道幅も広いのが 特徵で, 中心部シティ・ヒルの歩行者専用ゾーンに繋が るルートを対象とした.

各ケーススタディ地区で，360 度カメラを用いて歩行 空間を撮影した VR 動画を作成した. 各地区の歩行空間 デザインの特徵を把握するため，まず，この動画情報か ら客観的なデザイン指標の比較を行った. ここでは，各 対象地区のルートを 3 つに分し，それぞれの区分の 1 分間の動画部分について，指標の計測を行った. 1 つの 区分の長さは，交通状況や地形を考慮した成人の 1 分間 の歩行距離として $80 \mathrm{~m}$ 前後とした. 各区分の計測後, 3 つの区分の平均值を各地区で出した. 動画からの計測が 難しい歩道幅, 建物の高さ, 屋根のある歩行空間の長さ などは，Google Earth Pro を用いて計測した．また，道の 明るさは街灯の数で計測した.

デザイン要素の指標値は要素で異なるため, 各指標値 
を，最大值を 10 で最小值を 1 となるようにし，その間 の差を等分して評価值に変換して分析した. よって, 中 間值は最大值と最小值の分布で決まる。ここでは, デザ イン要素の量的な指標の計測を行っており, 量が多いも のを高い指標值としているため, 交通量が多い場合でも 指標值は高くなるが，その量がデザインの良し悪しを決 めるものではない，また，境界空間デザインとして，建 物側ではアクティビティの要素が，車道側では設置物の 要素が比較的多く見られたが，その要素の位置に関わら ず，各要素の歩行空間上の量を計測した.

各デザイン指標值の標準偏差の都市別平均は $1.6 \sim 2.0$ となり，都市内における区分間のデザインのばらつきは 大きくは見られなかった. この中で，バンコクの区分間 のばらつきが最も大きく, 駐車, 立ち座り, 露店, 建物 高さ，交通量では，標準偏差が 3〜5 であった。 これは, ルート上に高架歩道, 建物, 裏通り, 大通りが含まれる ためで, 空間の多様性を表している. 他の都市でばらつ きが大きいデザイン指標は, 名古屋では駐輪, 横断歩道, 緑, ブリスベンでは露店, 横断歩道, 施設, キャンベラ では, 屋根, ベンチ, 街灯, 横断歩道であった.

デザイン指標の都市別平均値を比較した結果, 名古屋 では，主に駐輪や街路樹の值が大きく，一方で，海外都 市ではアクティビティの值が大きいことが示された（図 -2）。特に，バンコクとブリスベンでは，立ち座りと露 店の值が大きく, キャンベラでは, ベンチの值が大きい. さらに，バンコクでは，交通量や駐車などの車道のデザ インの值も大きく, モータリゼーションが進むバンコク でも，歩道のアクティビティがブリスベンと同程度に多 いことは興味深い.これらの結果から，分析対象地区に おける歩行空間デザインの多様性が確認された.

一方で，天候も含めて実動画の環境条件をコントロー ル寸るには労力がかかることが, 調査方法の課題として 挙げられる. 本調査では, 可能な限り平日の日中に撮影 した動画を使用したが，キャンベラでは日暮れ時の撮影

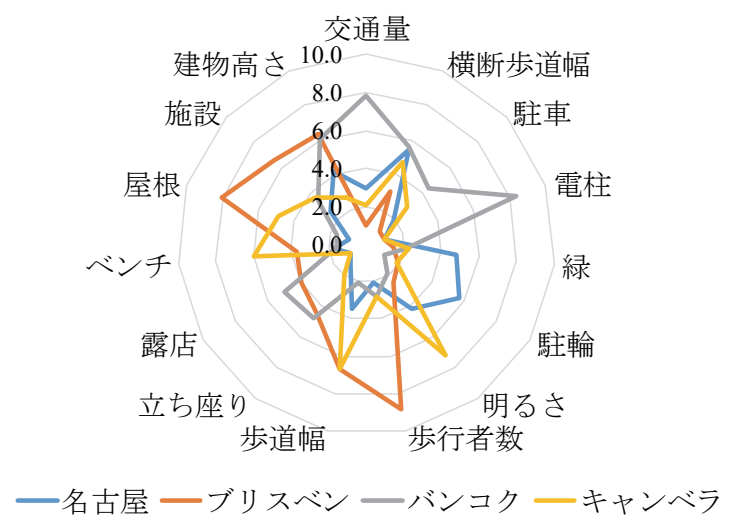

図-2 各ケーススタディ地区のデザイン指標
となり，照明の明るさが評価結果に表れた. そこで，こ のような環境要因もデザイン要素に含めて, その歩行空 間のニーズ評価との関係を分析する.

\section{3. 歩行空間デザインの VR 評価実験}

\section{(1) 調査方法}

本研究では, 360 度カメラで撮影した VR 動画を HMD で視聴する歩行空間デザインの評価実験を，2018 年 11 月 13 日〜 12 月 7 日に名城大学の学生 50 名を対象に行っ た. VR 動画は, 撮影者の歩行速度で再生するため, 被 験者は決められた歩行速度で頭の動きと連動した視点を 自由に変えることで疑似歩行する.

この調査は，日常では体験が難しい空間を疑似歩行す ることを目的として, 視覚と聴覚に関する空間情報を評 価するもので，実歩行の再現性の検証を目的とするもの ではない.VR 利用による過大・過小評価の懸念ついて は，事前にオープンキャンパスで行った実験では，単一 動画を VR の有無で比較した場合, VR 利用時は半分以 上の項目で高く統計的に有意な差が見られたが，複数動 画の比較をする際は，その差がほぼ見られなかった。 た だし，これは同一被験者に対して VR 有無による評価の 違いを検証したもので, 被験者が VR 視聴のみと一般視 聴のみで評価した場合の差は, まだ検討の余地がある. 本調査では，VR を用いた空間評価に注目し，VR 視聴 のみでケーススタディ評価の比較を行った. 各被験者の 調查は, 評価対象となる視聴動画の数と調查時間を考慮 して，2日に分けて行った（図-3）。1日目の調査は，ま ず被験者属性情報のアンケートを行い, 名古屋, ブリ スベンの評価を行った．2 日目は，バンコクとキャンベ ラの評価を行った， 2 日間に分けた理由は，長時間の VR 視聴による酔いの影響で正確な評価が行われなくな ることを防ぐためである. 各都市の組み合わせは，1 日 目は，被験者が見慣れた名古屋を視聴してからて，より 歩行空間整備が進んでいるブリスベンを視聴し，2 日目 は, 歩行空間整備が遅れているバンコクを視聴してから, より整備が進んだキャンベラを視聴した.これらの動画 の視聴の順番は，評価に影響するかもしれないが，これ は本研究では検証できておらず, 今後の課題とする.

各調査日において, 評価の前に VR 動画に慣れてもら うため, 対象地区以外の歩行空間の VR 動画を 1 分間視 聴してもらう。この理由は，VRに対する物珍しさや興 味などから, 最初に見た VR 動画に対して, 空間評価を 過大評価してしまうことを防ぐためである。ただし，2 日目は，VR 動画に慣れてもらうのと同時に前回の実験 のイメージを思い出してもらうために, 1 回目の実験で 視聴した名古屋地区の VR 動画を視聴してもらう。評価 
においては，評価対象である名古屋，バンコク，ブリス ベン, キャンベラの4つの地区のVR動画を，HMDを用 いて視聴してもらった. 各地区の評価は, 対象ルートを 3 つに区分した各区間について評価した．被験者は，各 地区の動画を視聴した後に，VR 酔いを防ぐため休㕰を 行った.

歩行空間の評価としては，デザイン評価と歩行ニーズ の知覚的評価についてアンケートを行った. デザイン評 価については，前章で示したデザイン要素の主観的デザ イン指標として量的な印象を，10 段階で評価した。デ ザイン要素を主観的に評価することで，被験者の評価の 影響要因の違いをより考慮することができると考える. また，知覚的評価については，歩行ニーズの知覚的な指 標として, 利便性, 安全性, 快適性・楽しさについて, 被験者が 10段階で評価した（表-2）。これらの歩行ニー ズは, 利便性, 安全性, 快適性・楽しさの順で階層的な 関係にあると言われている ${ }^{9}$. 本調査の具体的な指標は, 既往研究から抽出し，快適性や楽しさの指標に関しては SD 法を用いた街路景観評価で用いられている指標を参 考にした ${ }^{10)}$.

属性アンケートでは，性別，年齢，車とバイクの保有 率，よく利用する移動手段，よく行う活動の頻度，ケー ススタディの 1 つである名古屋の名古屋地区の認知度,

表-2 本研究で使用する歩行ニーズの知覚的指標

\begin{tabular}{|c|c|}
\hline \multirow{4}{*}{ 利便性 } & 移動が短く感じる \\
\hline & 移動の接続が良い \\
\hline & 移動の障害が少ない \\
\hline & 道がわかりやすい \\
\hline \multirow{3}{*}{ 安全性 } & 横断の危険が少ない \\
\hline & すれ違いの危険が少ない \\
\hline & 治安が良い \\
\hline \multirow{3}{*}{ 快適性 } & 街並みが良い \\
\hline & 天候から保護されている \\
\hline & くつろげる \\
\hline \multirow{3}{*}{ 楽しさ } & 䝽わいがある \\
\hline & 個性的である \\
\hline & 親しみがわく \\
\hline
\end{tabular}

\section{1日目}

海外の渡航経験を回答してもらった.この結果より，被 験者は男性26名と女性24名の19歳から23歳の学生で, 車の保有率は $64 \%$ ，バイク保有率は $14 \%$ であつた。移動 手段は，70\%が徒歩・自転車・公共交通を $25 \%$ が車を主 に利用しており，より歩行を伴う交通の利用頻度が比較 的高い層といえる.また, 活動頻度としては, 通学以 外では，アルバイト，友人との交流が多い.また，ケー ススタディの名古屋の栄地区について，66\%がよく知っ ている, 知っていると回答し, 58\%が, よく行く, 少し 行くと回答した。 そして, 海外の渡航経験は，42\%が渡 航経験がなく, 年 1 回以上の渡航経験があるのは $10 \%$ で あった。

\section{（2）客観的評価と主観的評価の比較}

本調査で得られた全ケーススタディ地区の主観的な歩 行空間デザイン評価の平均值と, 前章で示した客観的な 評価の平均值を比較した(図-4). まず，全てのデザイン において，正の相関があることが確認された．特に主観 的な評価と客観的な評価の関係が大きい指標は，交通量， 駐車，歩道幅，ベンチであった．歩道幅はこの関係が最 も大きく，被験者から最も距離が近いデザインなので印 象が大きいと考えられる. また, 交通量は, 動的な要素 として影響が大きいと考えられる。 さらに，ベンチや駐 車といった境界空間のデザインも，視覚的に印象に残 りやすいことが示された.

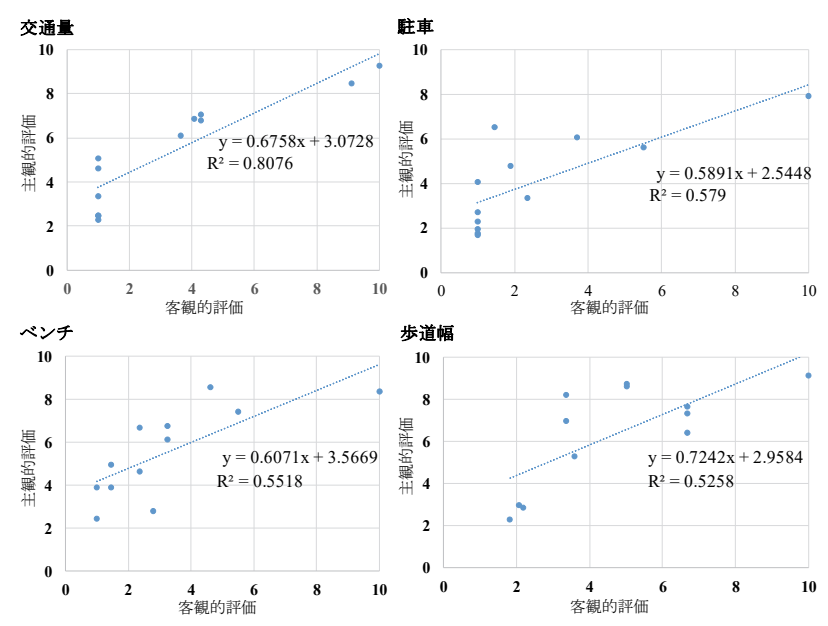

図-4 客観的な評価と主観的な評価の比較

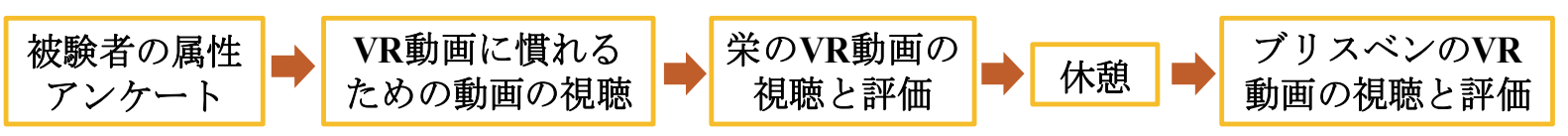

\section{2 日且}

\section{1 日目の最初に見た VR動画の視聴}
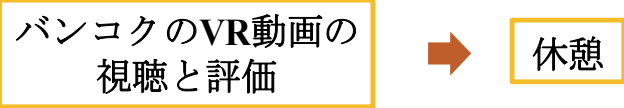

キャンベラのVR

動画の視聴と評価

図-3 VRを用いた歩行空間評価の実験調査フロー 


\section{4. 歩行空間評価の分析結果}

\section{（1） 歩行空間評価の国際比較}

ケーススタディ地区における歩行空間評価の特徵を把 握するため, デザインの主観的指標と歩行ニーズの知覚 的評価を，ケーススタデイ地区間で比較した。この結果, 名古屋と比較してバンコク，ブリスベン, キャンベラの 海外都市では，デザイン評価ではアクティビティや建物 の主観的評価が高く，歩行ニーズ評価では楽しさ，特に 賑わいや個性的，や快適性の評価が高いことが分かった

(図-5)。一方で，バンコクでは，交通量，駐車，電柱 等の車道側のデザインが多く，利便性，安全性，快適性 に関する項目が低い結果となった。これらの結果は，建 物側に多いデザイン要素が快適性や楽しさといった歩行 の高次ニーズに，車道側に多いデザイン要素が安全性や 利便性といった低次ニーズとより関係していることを示 していると考えられる.

\section{（2）境界空間デザインの評価}

歩道の境界空間デザインが，歩行ニーズの知覚的評価 に与える影響を分析するため, 重回帰分析を行った. デ 一タは，50人の被験者が4つのケーススタディ毎の 3 区
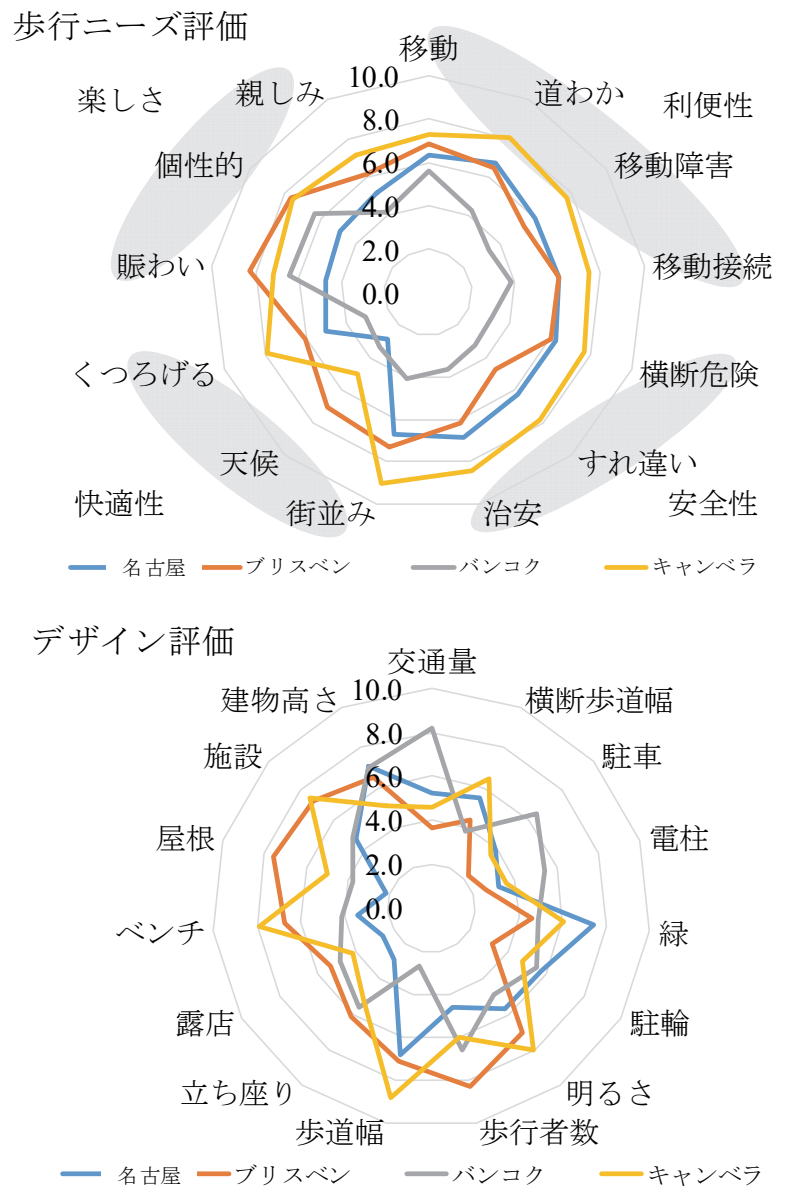

図-5 デザイン評価と歩行ニーズ評価の比較
分を評価した結果を用いているため, 総サンプル数は 600 となる. まず, 説明変数を整理するため, 15 個のデ ザイン指標に対して因子分析を行った（表-3）。この結 果, 歩道（施設, 歩道幅, 街灯の数) , アクティビティ (ベンチ，露店，立ち・座り），設置物（駐車，駐輪， 電柱）, 車道（横断歩道幅，交通量）の 4 因子が抽出さ れた. ここで，駐車は，設置物のデザイン要素と同じ因 子に含まれる結果となったため，そのように扱う。また， 因子に含まれなかった歩行量，建物高さ，緑の 3 指標も， 説明変数に加えた.

被説明変数を歩行ニーズの評価指標として重回帰分析 を行った結果, 歩道と歩行量に加え, 境界空間デザイン のアクティビティと設置物が歩行ニーズの評価と関係が 大きいことが示された（表-4）。歩行ニーズとの関係の 違いとして，歩道は利便性や安全性の低次ニーズにより 関係するが，アクティビティと設置物は，快適性や楽し さの高次ニーズとより関係する結果となった．設置物は， 障害物として快適性や安全性により大きく負の関係が示 されたが，利便性にも負の関係がある。これは，物を設 置をしない方が歩きやすいという結果であるが，乗り換 えの観点からの評価は結果に表れていないため，この考 慮が今後の課題である.

一方で，歩行量やアクティビティは，ニーズによって

表-3 因子分析の結果

\begin{tabular}{|c|c|c|c|c|}
\hline & 因子 1 & 因子2 & 因子 3 & 因子 4 \\
\hline 中が見える施設の数 & 0.5 & 0.37 & 0.02 & 0.12 \\
\hline 屋根のある歩道の長さ & 0.13 & 0.54 & 0.22 & 0.13 \\
\hline ベンチの数 & 0.45 & 0.62 & 0.14 & 0.1 \\
\hline 露店の数 & -0.03 & 0.58 & -0.19 & -0.02 \\
\hline 立止まる・座る人の数 & -0.03 & 0.66 & -0.01 & -0.02 \\
\hline 歩道幅 & 0.87 & -0.06 & 0.26 & 0.13 \\
\hline 街灯の数 & 0.71 & 0.15 & 0.08 & 0.02 \\
\hline 駐輸の数 & -0.16 & 0.2 & 0.67 & 0.07 \\
\hline 電柱の数 & 0.2 & -0.11 & 0.58 & 0.13 \\
\hline 駐車の数 & 0.18 & -0.1 & 0.79 & 0.21 \\
\hline 橫断歩道の幅 & -0.53 & 0.06 & 0.14 & 0.37 \\
\hline 交通量の数 & 0.1 & 0.04 & 0.49 & 0.81 \\
\hline
\end{tabular}

表-4 重回帰分析の結果

\begin{tabular}{|c|c|c|c|c|c|c|c|c|}
\hline & \multicolumn{2}{|c|}{ 利便性 } & \multicolumn{2}{|c|}{ 安全性 } & \multicolumn{2}{|c|}{ 快適性 } & \multicolumn{2}{|c|}{ 楽しさ } \\
\hline & B & T値 & B & T值 & B & T值 & B & T値 \\
\hline 歩道 & $0.67 * *$ & 27.35 & $0.56^{* *}$ & 22.26 & $0.51 * *$ & 20.28 & $0.20^{* *}$ & 7.53 \\
\hline $\begin{array}{c}\text { アクティ } \\
\text { ビティ }\end{array}$ & - & - & $-0.08 * *$ & -3.19 & $0.22 * *$ & 8.52 & 0.49 ** & 18.35 \\
\hline 設置物 & $\begin{array}{c}-0.19 \\
* *\end{array}$ & -7.33 & $-0.22 * *$ & -8.31 & $-0.32 * *$ & -12.12 & $-0.13^{* *}$ & -4.85 \\
\hline 車道 & - & - & $-0.09 * *$ & -3.48 & $-0.06 *$ & -2.17 & - & - \\
\hline 歩行者数 & - & - & $-0.27 * *$ & -10.19 & $-0.12 * *$ & -4.33 & $0.31 * *$ & 11.33 \\
\hline 建物高さ & $0.05 *$ & 2.05 & $0.11 * *$ & 3.85 & $0.09 * *$ & 3.33 & $0.07 *$ & 2.52 \\
\hline 緑 & $0.10 * *$ & 3.78 & $0.08 * *$ & 3.18 & $0.13 * *$ & 4.97 & - & - \\
\hline $\mathrm{R}^{2}$ & \multicolumn{2}{|c|}{0.60} & \multicolumn{2}{|c|}{0.59} & \multicolumn{2}{|c|}{0.58} & \multicolumn{2}{|c|}{0.54} \\
\hline サンプル数 & \multicolumn{8}{|c|}{600} \\
\hline
\end{tabular}

B:標準偏回帰係数 $\quad{ }^{*} \mathrm{p}<0.05,{ }^{* *} \mathrm{p}<0.01$ 
関係の方向が異なった. 歩行者数は, 高次ニーズの楽し さには正の関係があるが，それ以外のより低次な安全性 や快適性のニーズとは負の関係がある。これは，賑わい と障害の両面の観点から評価されたことを示している.

同様に，アクティビティは，快適性と楽しさと正の関係 があり, 安全性には負の関係がある。これは, アクティ ビティが増えることで, 快適性や楽しさは高めるかもし れないが，安全性は低下寸るかもしれない，ことを意味 している.これらの結果から, 境界空間のデザイン要素 が, 複数の空間機能に異なる関係があることを表すこと が出来た.

\section{5. 結論}

本研究では, 歩道の境界空間デザインを考慮して, 歩 行空間デザインの VR 評価を行った. 名古屋, バンコク, ブリスベン，キャンベラの 4 つの都市の歩行空間のデザ イン指標を国際比較した結果，日本と比較すると海外の 都市では, 建物側の境界空間でより見られるデザイン要 素として，アクティビティが多いことが明らかになった。 さらに, バンコクでは, 車道側に多い境界空間デザイン として交通量や駐車も多く, モータリゼーションとアク ティビティの混在が特徴的であると言える.

また，VR ツールを用いて歩行空間デザインを評価し た結果, 異なるタイプのデザイン要素について客観的評 価と主観的評価の間に関係が見られた。被験者の視点か ら近い歩道のデザイン要素は，客観的要素の変化に対す る主観的評価の変化の感度が大きく，その印象が大きい といえる. また, 動的なデザイン要素である交通量に加 え，境界空間のデザイン要素であるベンチや駐車が，視 覚的な印象が大きい要素であることが示された.

さらに, 歩行空間デザインの主観的評価と歩行ニーズ の知覚的評価の関係を分析した結果, 境界空間デザイン と歩行ニーズには関係があることが分かった。ここでは, 境界空間デザイン要素が他のデザイン要素と比べて歩行 ニーズ評価と関係が大きく，建物側で多い要素と車道側 で多い要素がともに，快適性や楽しさといった高次ニー ズにより関係することが明らかになった。 また，アクテ イビティは, 歩行ニーズによって正負の関係の向きが異 なり, 歩行空間の複数機能に異なる関係があることが示 された。

これらを踏まえ，本研究では，境界空間デザインの多 様な空間機能に対する重要性が示された. 歩行空間にお けるアクティビティや駐車・駐輪の量を検討する上では, 複数の機能への影響を検討寸ることが重要である.この ようなデザイン要素と包括的な歩行ニーズに与える影響 を考慮した歩行空間評価モデルは, 複数の空間機能が共
存できる歩行空間整備の検討に有用であると考えられる. 例えば，昨今増加する高齢者による自動車事故の防止に ついて，ガードレールの設置の議論が高まっているが, これは歩行空間の楽しさを奪うものであるかもしれない. また，このようなデザイン評価において何を重視するか は，歩行者の特性によっても異なるであろう。ささらに, 包括的なニーズを評価する上で，国内外の多様な歩行空 間を疑似体験出来るVR 技術の活用は，今後の計画ツー ルとして潜在性が高いと期待される．今後は，歩行空間 の乗り降りの交通機能の評価や歩行者特性の考慮といっ た点に関して評価手法の改良を行うことで，その有用性 を高められると考える.

謝辞 : 本研究は, JST easia Joint Research Program（研究課 題 : スマートライフを実現する知的統合交通）と， JST/JCA SATREPS（研究課題 JPMJSA1704 : Thailand4.0 を 実現するスマート交通戦略）の支援により実施された. ここに記して謝意を表する.

\section{参考文献}

1) Speck, J.: Walkable City, North Point Press, New York, 2012.

2) Gehl, J. and Svarre, B.: How to Study Public Life, pp. 70, 100, 2013.

3) Ewing, R. and Bartholomew, K.: Pedestrian- and Transitoriented Design, Urban Land Institute, pp. 10-54, 2013.

4) 藤本和夫, 嘉名光市, 赤崎弘平: 公共空間を利用し たオープンカフェの利用実態と住民意識に関する研 究一広島市京橋河川岸のケーススタディ一, 日本都 市計画学会都市計画論文集, No. 43-3, pp. 619-624, 2008.

5) 有馬隆文, 大木健人, 出口敦, 坂井猛: 商業地街路 における行動誘発要素と歩行者のアクティビティに 関する基礎的研究一五感を刺激する商業地デザイン と来訪者のアクティビティ（その 1) 一, 日本建築学 会計画系論文集, No. 623,pp. 177-182, 2008.

6) 松本直司, 清田信也, 伊藤美穂 : 街路空間特性と歩 行速度の関係, 日本建築学会計画系論文集, No. 640, pp. 1371-1377, 2009.

7) 谷口綾子, 香川太郎, 藤井聡 : 商店街における自動 車交通が歩行者に及ぼす心的影響分析, 土木計画論 文集 D, No. 3, pp. 329-335, 2009.

8) 藤居良夫, 酒井裕一：街路景観評価に関する因果関 係の分析, 日本都市計画学会学術論文集, No. 175, pp. 1045-1050, 2002.

9) Alfonzo, M.: To walk or not to walk; The hierarchy of walking needs, Environment and Behaviour, Vol. 37, pp. 808836, 2005.

10) 中村一樹：疑似体感型 Walkability 評価の基礎的分析, 都市計画論文集，Vol. 53, pp. 589-596, 2018.

(Received June 21, 2019) (Accepted January 14, 2020) 


\section{WALKABILITY EVALUATION WITH VIRTUAL REALITY FOR STREET EDGE SPACE DESIGN}

\section{Kenji MORITA and Kazuki NAKAMURA}

Walking space has several functions to do with walking needs, such as convenience and safety for passing by and getting on/off vehicles and comfort and attractiveness for staying and making on-street activities. However, it is hard to say that street improvements sufficiently take account of the influences on the multiple functions. Therefore, this research analyzes the influence on walkability evaluation of the street-edge design of in-between spaces on building sides and on road sides, by evaluating internationally diverse street environments through experiencing the walk in virtual reality (VR) environments. First, street design elements are compared among international case study streets. Then, using the VR tool, the experiment is conducted to evaluate the street design of the case studies and the perception of walking needs. As a result, the street edge design significantly influences multiple walking needs, which is different by the design elements of building-side design and road-side design. 